\title{
Delta de l'Ebre is a natural bay model for Marteilia spp. (Paramyxea) dynamics and life-cycle studies
}

\author{
N. Carrasco ${ }^{1,5}$, I. Arzul ${ }^{2}$, F. C. J. Berthe ${ }^{2,3}$, M. Fernández-Tejedor ${ }^{1,5}$, M. Durfort ${ }^{4}$, \\ M. D. Furones ${ }^{1,5, *}$ \\ ${ }^{1}$ IRTA, St. Carles de la Ràpita 43540, Spain \\ ${ }^{2}$ Laboratory of Genetics and Pathology, IFREMER, La Tremblade 17390, France \\ ${ }^{3}$ Department of Pathology and Microbiology, Atlantic Veterinary College, University of Prince Edward Island, \\ Charlottetown, Prince Edward Island C1A 4P3, Canada \\ ${ }^{4}$ Department of Cellular Biology, University of Barcelona, Barcelona 08028, Spain \\ ${ }^{5}$ Aquaculture Reference Centre of Catalonia (CRAq), 08007, Spain
}

\begin{abstract}
Marteilia spp. are paramyxean parasites that affect several bivalve species of economic interest, such as Ostrea edulis and Mytilus galloprovincialis. Certain aspects of Marteilia spp., such as their life cycle and host affinity and infection dynamics, still remain unknown. The 'Delta de l'Ebre' constitutes a natural model for the study of the life cycle of the parasite Marteilia, since uninfected mussels and flat oysters immersed in the bays can become infected. This, along with the geographical and ecological characteristics of the bays, make it a very interesting location to study the Marteilia life cycle. Preliminary results concerning marteiliosis, mainly in mussels, such as prevalence dynamics, infectious periods, host affinity and host intermediate candidates are reported in the present paper. This information will be required for further, more exhaustive, studies in the bays of the Ebre delta.
\end{abstract}

KEY WORDS: Marteilia · Paramyxea $\cdot$ Mytilus galloprovincialis $\cdot$ Intermediate host $\cdot$ Host specificity · Ebre delta bays Resale or republication not permitted without written consent of the publishe

\section{INTRODUCTION}

Paramyxean parasites of the genus Marteilia affect some marine bivalve molluscs of economical interest such as the European flat oyster Ostrea edulis, and the blue mussel Mytilus galloprovincialis and M. edulis, which are important aquaculture species in Europe.

Historically, Marteilia species have been responsible for high mortalities in mollusc cultures in European countries. More particularly, $M$. refringens affects flat oysters in estuaries, bays and lagoons from a northern limit in Brittany on the French Atlantic coast to a southern limit identified as being the Mediterranean Sea (Comps 1979). Due to the detrimental impact of this parasite on flat oyster cultures since the 1970s, infection with $M$. refringens has been listed as a disease notifiable to the OIE (the World Organisation for Ani- mal Health). The parasite has been a subject for study and scientific investigations since its first description in 1968 in the Aber Wrach, Brittany, France (Comps 1970). More than 3 decades of research have clarified many taxonomical, epidemiological and pathological aspects of the disease (Herrbach 1971, Grizel et al. 1974, Perkins 1976, Balouet 1977, Berthe et al. 1998, 2000, 2004, Le Roux et al. 2001, Longshaw et al. 2001, Audemard et al. 2002, Lopez-Flores et al. 2004, Novoa et al. 2005). However, this organism still presents questions regarding its host affinity, infection dynamics and life cycle.

In Europe, 2 species or types of Marteilia, M. refringens and M. maurini, are responsible for marteiliosis of oysters and mussels, respectively (Le Roux et al. 2001). Recent studies, based on molecular data, suggest that both parasites, $M$. refringens and $M$. maurini, are con- 
specific and correspond to 2 types of the same genomic species (Lopez-Flores et al. 2004), most probably undergoing an alloxenic speciation process. However, these molecular results have to be confirmed based on robust epidemiological and ecological datasets.

More information is required to control disease emergence, to monitor infested cultures and to clarify the ecological behaviour of the 2 different Marteilia types infecting oysters and mussels in Europe.

Host affinity studies have investigated the relative host specificity of the 2 types of Marteilia with respect to their molluscan hosts. Results showed some cases of co-infection (both types in the same individual) and a lack of a strict host specificity (Le Roux et al. 2001, Lopez-Flores et al. 2004, Novoa et al. 2005). This has important consequences for further understanding of the transmissibility of the disease and to establish monitoring strategies.

Comparative studies of Marteilia types and their ecology also appear important in a polyphasic approach to their relative taxonomic relations. Indeed, the hypothesis of co-specificity might be confirmed if both Marteilia types were to present similar behaviour and dynamics in mussels as well as in flat oysters. Marteiliosis evolution and distribution have been well documented for Ostrea edulis. Many studies have been conducted on $M$. refringens in flat oysters, with particular emphasis on the transmission period, the annual dynamics of the parasite, and its life-stage distribution over time and within tissues. In mussels, studies describing annual patterns of infection intensity, spatial distribution and pathogenesis have been published (e.g. Villalba et al. 1993). However, more information is necessary to compare the disease profiles in flat oysters and mussels.

Since 1968, several experiments to transmit the disease to non-infected flat oysters have been attempted without success (Balouet 1977, Comps \& Joly 1980, Berthe et al. 1998). Results of these experiments supported the hypothesis of a heterogenic life cycle including an intermediate host. To investigate this hypothesis, an interesting experimental model was designed based on natural ponds with low biodiversity (Audemard et al. 2001). These ponds, also known as 'claires', reduce the high number of potential hosts present in the estuarine areas. Claires are shallow ponds traditionally used for fattening and greening oysters and where the Marteilia refringens life cycle was demonstrated to be completed. This model has facilitated the initial screening step of research for an intermediate host by decreasing the biodiversity 10fold compared to that in estuaries. Audemard et al. (2001) demonstrated that Paracartia [Acartia] grani (Copepoda) is an alternate host of $M$. refringens and could be an intermediate host in the parasite life cycle
(Audemard et al. 2002). The use of molecular tools (Le Roux et al. 1999) facilitated research in this field by screening for $M$. refringens DNA in the different species living in the claires.

The experimental transmission of the parasite to mussels did not provide conclusive results, except for a unique equivocal report of transmission from oysters to mussels (Comps \& Joly 1980). Thus, again, the hypothesis of a heteroxenic life cycle and an intermediate host was postulated (Balouet 1977, Berthe et al. 1998). However, no potential intermediate host has been proposed for the Marteilia infection in mussels.

The claire pond model for marteiliosis provided important preliminary data to design a more natural and comprehensive study model in order to answer unresolved questions, especially concerning Marteilia in mussels.

In the estuarine bays of the Ebre River (NW Mediterranean coast of Spain), Marteilia has been recorded in both oysters and mussels (Riera et al. 1993, Durfort et al. 1996, Carrasco et al. 2001). The dimensions of the bays, their hydrodynamics, biodiversity and shellfish aquaculture make them an interesting choice as a natural model to further our knowledge of the Marteilia spp. cycle.

The current paper presents the dynamics of the parasite in 2 bays of the Ebre delta, and the relationship with key environmental factors. Preliminary comparative studies on host affinity and determination of the main zooplankton species present in the bays were carried out. These preliminary data are indispensable for further studies using this model.

\section{MATERIALS AND METHODS}

Study site. The Ebre delta is located in the northwestern Mediterranean (Fig. 1). Sediments of the Ebre River form this delta, which encompasses 2 semienclosed bays: the northern Fangar Bay and the southern Alfacs Bay.

The delta is a complex water system. River water is diverted into a channel system $50 \mathrm{~km}$ upstream of the river outlet to be used in rice and horticulture production. After agricultural use it drains from the fields into Fangar Bay (with a capacity of $10 \mathrm{~m}^{3} \mathrm{~s}^{-1}$ ) to the north and Alfacs Bay (with a capacity of $13 \mathrm{~m}^{3} \mathrm{~s}^{-1}$ ) to the south (Camp \& Delgado 1987). Freshwater supply exceeds evaporative loss in both Fangar and Alfacs Bay (Camp \& Delgado 1987). Both bays receive approximately the same quantities of freshwater, whereas the residence times in the bays are different. The annual average salinity in the bays is $35 \%$ (slightly below the salinity of the open sea, 37 to $38 \%$ ), but salinity variation is very pronounced. Temperatures during the year range from 8 to $28^{\circ} \mathrm{C}$, with some exceptions in particu- 


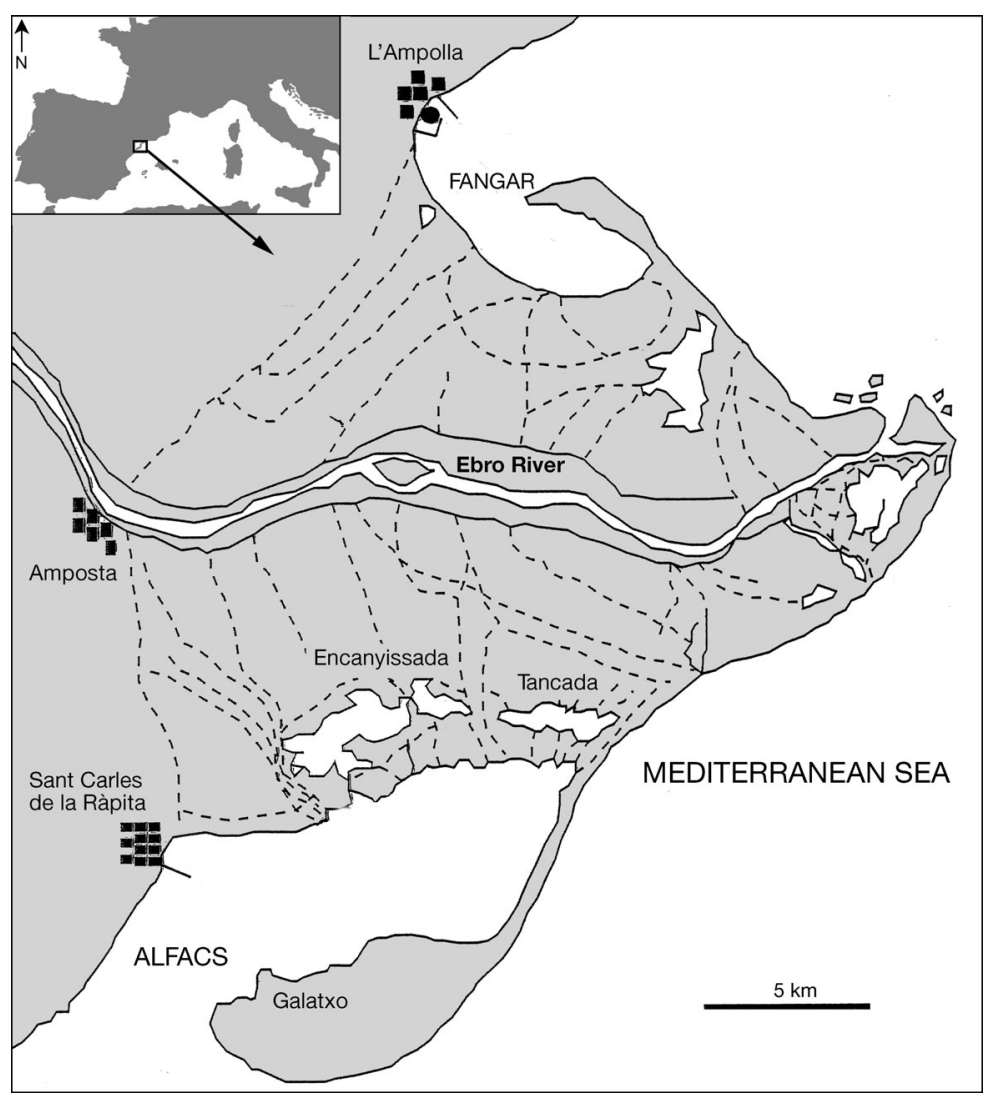

Fig. 1. Study site: Delta de l'Ebre, Catalonian coast, north eastern Spain

experimental 2003 culture period, from February to December 2003. For the second experimental period (October 2003 to September 2004), temperature and salinity were recorded every hour using a SBE 16 plus moored at $2 \mathrm{~m}$ depth.

Mollusc experimental cultures. Blue mussels Mytilus galloprovincialis, European flat oyster Ostrea edulis and Pacific oysters Crassostrea gigas were used as experimental animals. They were cultivated on ropes prepared according to local farming practices. Ropes were deployed in both bays as described below.

2003 experiments: Mussel ropes were set up with spat (30 $\mathrm{mm}$ average size) naturally collected within the Alfacs Bay and on the Maresme coast (north of Barcelona) in February 2003. Flat oyster ropes were prepared in March of 2003 with oysters (1 yr old, $65 \mathrm{~mm}$ average size) originating in French Mediterranean and Italian Adriatic waters. Pacific oyster ropes were prepared in February of 2003 with spat (4 $\mathrm{mm}$ average size) originating from Marennes-Oleron, France. All cultures were placed in both bays in duplicate.

2003/2004 experiments: Mussel ropes were prepared in October 2003 with spat (32 $\mathrm{mm}$ average size) originating in the

lar cases. The studied bays have a maximum depth of $6 \mathrm{~m}$. The tides have a maximum amplitude of $20 \mathrm{~cm}$, and the alternation between a stratified and mixed water column in the annual cycle is determined by seasonal winds (Delgado \& Camp 1987).

Fangar Bay has an extension of $10 \mathrm{~km}^{2}$, a maximum depth of $4 \mathrm{~m}$, a capacity of $16 \times 10^{6} \mathrm{~m}^{3}$ and is open to the sea across a $1 \mathrm{~km}$ mouth. Freshwater retention time is an average of $1 \mathrm{~d}$, which produces short fluctuations in temperature and salinity ( 1 to $2 \mathrm{~d}$ ). The annual average chlorophyll a concentration in this bay is $3.44 \mathrm{mg}$ $\mathrm{m}^{-3}$ (Delgado 1987).

Alfacs Bay has an extension of $50 \mathrm{~km}^{2}$, a maximum depth of $6 \mathrm{~m}$, a capacity of $191 \times 10^{6} \mathrm{~m}^{3}$ and is open to the sea across $3 \mathrm{~km}$. Freshwater retention time is $10 \mathrm{~d}$ and, therefore, fluctuations of temperature and salinity are longer (10 to $20 \mathrm{~d}$ ). The annual average chlorophyll a concentration in this bay is $3.20 \mathrm{mg} \mathrm{m}^{-3}$ (Delgado 1987). Different species of Acartia spp. (Copepoda) have been reported to form part of the zooplankton community in this bay (M. Alcaraz pers. comm.).

Both bays are exploited for mollusc aquaculture and fisheries. For the purpose of the present study, temperature and salinity were measured weekly at $2 \mathrm{~m}$ depth using a manual conductivity meter (WTW) during the northern Italian Adriatic and the French Mediterranean. Flat oyster ropes were prepared in May of 2004 with 1 yr old (60 mm average size) oysters originating from Galicia, Spain. Duplicates of these ropes were placed in both bays. Pacific oyster ropes used in 2004 were the same as in 2003.

Sampling strategy. Epidemiological study in the Ebre Delta: A total of 60 individuals in 2003 and 150 individuals in 2003/2004 were collected from each species in both bays every 3 mo over the 2 yr period in order to be able to detect 5 and $2 \%$ of prevalence, respectively (Ossiander \& Wedemeyer 1973). Additionally, 150 mussels deployed in a site of Fangar Bay were sampled monthly during late spring and summer in 2004, to provide a more detailed description of parasite dynamics during this period.

Zooplankton sampling: An initial sampling of zooplankton was performed in October 2003, as a first preliminary analysis, and then every $2 \mathrm{wk}$ from June to August 2004. Horizontal net hauls using $100 \mu \mathrm{m}$ mesh were performed for zooplankton sampling. Zooplankton was fixed in $10 \%$ formaldehyde in filtered seawater and observed using a stereomicroscope (Nikon SMZ800) for identification. Furthermore, qualitative abundance was noted for each taxon. 
Histology. Specimens were measured and analysed by histology to establish their status regarding marteiliosis. Other parasites and proliferative diseases observed were also recorded. Samples were placed in $10 \%$ formalin in sterile seawater, and, after dehydration and paraffin embedding, tissues were cut $3 \mu \mathrm{m}$ thick and stained with haematoxylin and eosin (H\&E). Slides were examined under light microscopy (Carl Zeiss, Axiostar 34241).

Molecular biology. To study the types of Marteilia present in the Ebre delta, 6 flat oysters and 3 mussels that were established to be positive by histology during the epidemiological 2003 study were used for molecular studies.

DNA extraction: Soft tissues, which had been stored at $-20^{\circ} \mathrm{C}$, of the positive individuals were used for DNA extraction. After grinding, samples were suspended in $10 \mathrm{vol}$ of extraction buffer ( $\mathrm{NaCl} 100 \mathrm{mM}, 10 \mathrm{mM}$ Tris [pH 8], 2.5 mM EDTA [pH 8], SDS 0.5\%) containing Proteinase $\mathrm{K}\left(100 \mu \mathrm{g} \mathrm{ml} \mathrm{m}^{-1}\right)$. Following an overnight incubation at $55^{\circ} \mathrm{C}$, DNA was extracted using a standard protocol with phenol/chloroform extraction followed by ethanol precipitation (Sambrook et al. 1989).

DNA amplification and cloning: Polymerase chain reaction (PCR) analysis was performed, as described by Le Roux et al. (1999), with 2 different pairs of primers. A pair of universal primers (CS1/CAS1 eukaryotic species, including Marteilia spp.) was used as an internal control of DNA quality. A second pair, Pr4/5, was specific for Marteilia species ITS1 (Le Roux et al. 2001). PCR reactions were carried out according to the standard conditions for Silver-star Taq polymerase (Eurogenetec). After a denaturation step at $94^{\circ} \mathrm{C}$ for 5 min, 30 cycles were run with a PTC-100 ${ }^{\mathrm{TM}}$ thermocycler (MJ Research) as follows: denaturation at $94^{\circ} \mathrm{C}$ for $1 \mathrm{~min}$, annealing at $55^{\circ} \mathrm{C}$ for $1 \mathrm{~min}$ and elongation at $72{ }^{\circ} \mathrm{C}$ for $1 \mathrm{~min}$. A final elongation step at $72^{\circ} \mathrm{C}$ for $10 \mathrm{~min}$ was performed. Amplified products

Table 1. Prevalence of Marteilia spp. in bivalve cultures (Mytilus galloprovincialis, Ostrea edulis, Crassostrea gigas) representative of commercial production in Alfacs Bay in 2003. Table also shows the spat origin. A: Alfacs; I: Italy; Fr: France; -: not sampled

\begin{tabular}{|lcccc|}
\hline $\begin{array}{l}\text { Sampling } \\
\text { date }(2003)\end{array}$ & Mussel & A $(\%)$ & \multicolumn{3}{c|}{ Flat oyster } & I $(\%)$ & Pacific oyster \\
\cline { 5 - 6 } Feb & - & - & - & - \\
Mar & - & 0 & - & - \\
May & 1.67 & 0 & 1.67 & 0 \\
Jul & 0 & 5 & 5 & 0 \\
Nov & - & 3.34 & - & - \\
& & & & \\
\hline
\end{tabular}

were analysed electrophoretically on $1 \%$ agarose gels and cloned using the pCR 2.1 Vector System (Invitrogen). Minipreps of recombinant plasmids were prepared according to standard alkaline lysis protocols with an additional phenol/chloroform extraction and ethanol precipitation (Sambrook et al. 1989).

Restriction-fragment length polymorphisms (RFLP): PCR was performed with Primer Pair 4/5, and, as template, DNA was extracted from recombinant plasmids (10 to 15 cloned amplicons for each Marteilia spp. infected animal). Polymorphisms among the PCR products were identified by Hha1 enzymatic digestion (Promega) as described in Le Roux et al. (2001). The resulting restriction fragments were analysed electrophoretically on $2 \%$ agarose gels.

\section{RESULTS}

\section{Epidemiological studies}

$$
2003 \text { study }
$$

Detection of Marteilia spp. was sporadic in flat oysters Ostrea edulis and mussels Mytilus galloprovincialis from both bays, whereas no Pacific cupped oysters Crassostrea gigas were found to be infected. Recorded prevalence values mostly ranged between 1 and 3 out of 60 individuals (1.67 to $5 \%$ ) (Tables 1 \& 2). Uninfected flat oysters from the Italian Adriatic coast became infected in both bays in July/August. Important differences were observed in November, when 10 out of 60 flat oysters $(16.67 \%$ ) were parasitized in Fangar Bay, whereas, in Alfacs Bay, 2 out of 60 individuals (3.34\%) were infected (Fig. 2). Other parasites such as the ciliates Ancistrocoma spp. (in 1 individual in the Alfacs November sample), the copepods Myticola spp. (in 1 out of 60 individuals in the Fangar November sample) and the trematodes Bucephalus haimeanus (between 2 and 10 out of 60 parasitized individuals in the Alfacs and in 1 out of 60 individuals in the Fangar 


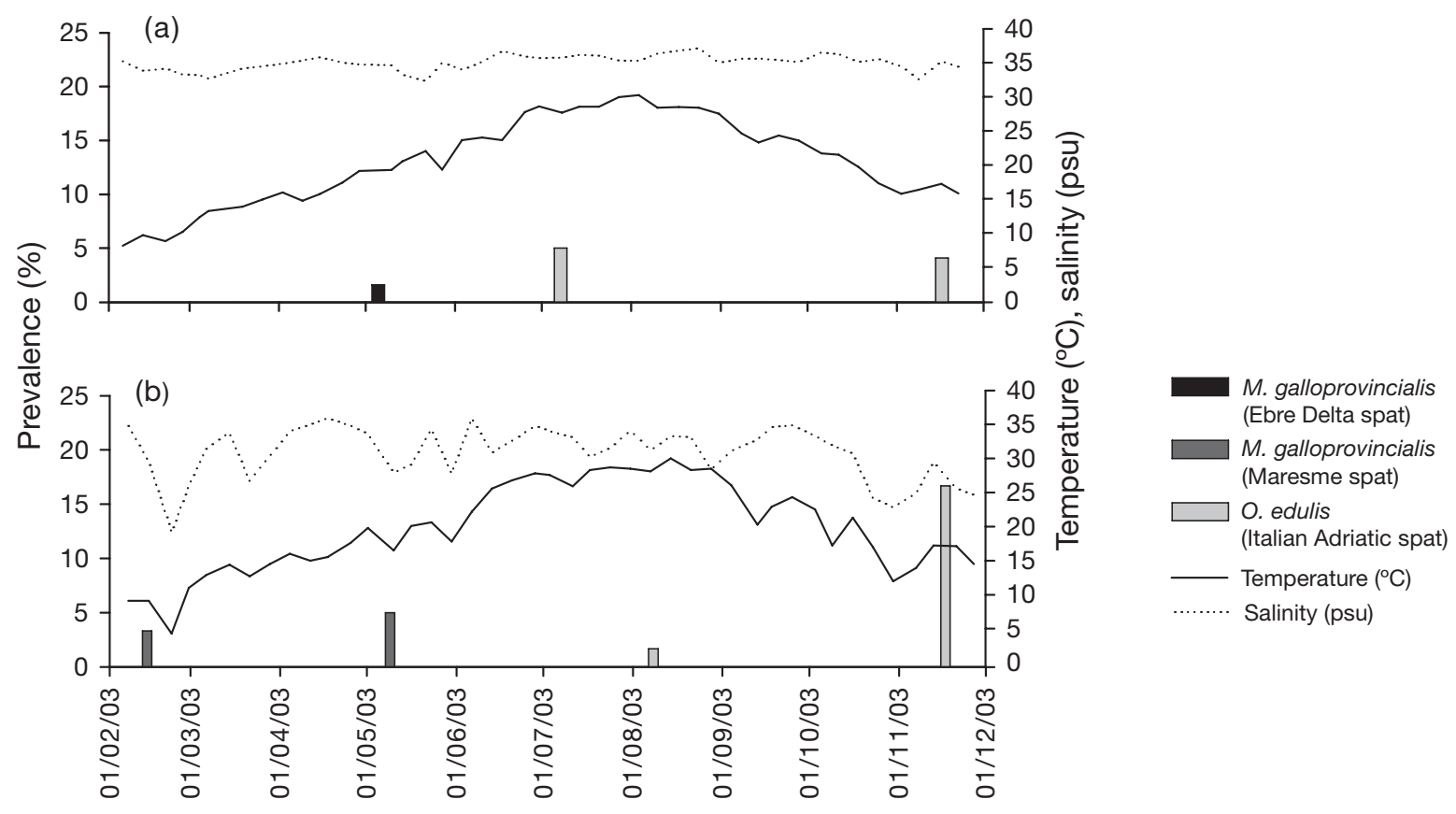

Fig. 2. Marteilia spp. prevalence (\%) in the cultivated bivalves (Mytilus galloprovincialis, Ostrea edulis, Crassostrea gigas) from the Ebre River delta in 2003: (a) in Alfacs Bay and (b) in Fangar Bay. Complementary environmental data: temperature $\left({ }^{\circ} \mathrm{C}\right)$ and salinity (psu). Dates given as d/mo/yr

sample) were also detected in Ostrea edulis samples. These parasites were not present in mussel or Pacific oyster samples during the same period. Due to unusually high temperatures $\left(>28^{\circ} \mathrm{C}\right)$, mussels showed $100 \%$ mortality in mid-June in Alfacs Bay and in mid-August in Fangar Bay. New mussel spat, of different origins, were introduced for producers using the bays of the Ebre River delta, to yield a subsequent culture crop.

\section{3/2004 study}

In October 2003, before the experimental ropes were submerged in the bays, a preliminary screening was carried out to assess the status of the different stocks. No infected individuals were detected for Adriatic Ital-

Table 3. Prevalence of Marteilia spp. in bivalve cultures (Mytilus galloprovincialis, Ostrea edulis) representative of commercial production in Alfacs Bay in 2003/2004. Table also shows the spat origin. I: Italy; Fr: France; G: Galicia, Spain; -: not sampled

\begin{tabular}{|c|c|c|c|}
\hline \multirow{2}{*}{$\begin{array}{l}\text { Sampling } \\
\text { date }\end{array}$} & \multicolumn{2}{|c|}{$\longrightarrow$ Mussel -} & \multirow{2}{*}{$\begin{array}{c}\text { Flat oyster } \\
\text { G (\%) }\end{array}$} \\
\hline & $\mathrm{I}(\%)$ & $\operatorname{Fr}(\%)$ & \\
\hline Oct 2003 & 0 & 6.67 & - \\
\hline Feb 2004 & 0.60 & 18.49 & - \\
\hline Mar 2004 & - & - & 0 \\
\hline May 2004 & 0.60 & 20.60 & 0 \\
\hline Jul 2004 & 3.30 & 15.21 & - \\
\hline
\end{tabular}

ian mussels, whereas $6.67 \%$ of the French mussels were infected (Tables $3 \& 4$ ). Prevalence data for both the Mytilus galloprovincialis samples (French and Italian origin) are shown in Fig. 3 for both bays (a and b/c). Additional samples were taken in Fangar Bay between May and September 2004 for the mussel of French origin, to assess the infection period more accurately (Fig. 3c). Only 1 out of $150(0.60 \%)$ Adriatic Italian mussels cultured in Alfacs Bay was parasitized in February and May. This prevalence increased to $3.34 \%$ in July. In Fangar Bay, no infected individuals could be detected in October, February or May, whereas $13.34 \%$ of the individuals were found parasitized in August.

Table 4. Prevalence of Marteilia spp. in bivalve cultures (Mytilus galloprovincialis, Ostrea edulis) representative of commercial production in Fangar Bay in 2003/2004. Table also shows the spat origin. I: Italy; Fr: France; G: Galicia, Spain -: not sampled

\begin{tabular}{|c|c|c|c|}
\hline \multirow{2}{*}{$\begin{array}{l}\text { Sampling } \\
\text { date }\end{array}$} & \multicolumn{2}{|c|}{ _ Mussel } & \multirow{2}{*}{$\begin{array}{c}\text { Flat oyster } \\
\text { G (\%) }\end{array}$} \\
\hline & I (\%) & Fr $(\%)$ & \\
\hline Oct 2003 & 0 & 6.67 & - \\
\hline Feb 2004 & 0 & 14 & - \\
\hline Mar 2004 & - & - & 0 \\
\hline May 2004 & 0 & 9.30 & 0 \\
\hline Jun 2004 & - & 18.67 & 0 \\
\hline Jul 2004 & - & 12 & - \\
\hline Aug 2004 & 13.34 & 18 & - \\
\hline
\end{tabular}




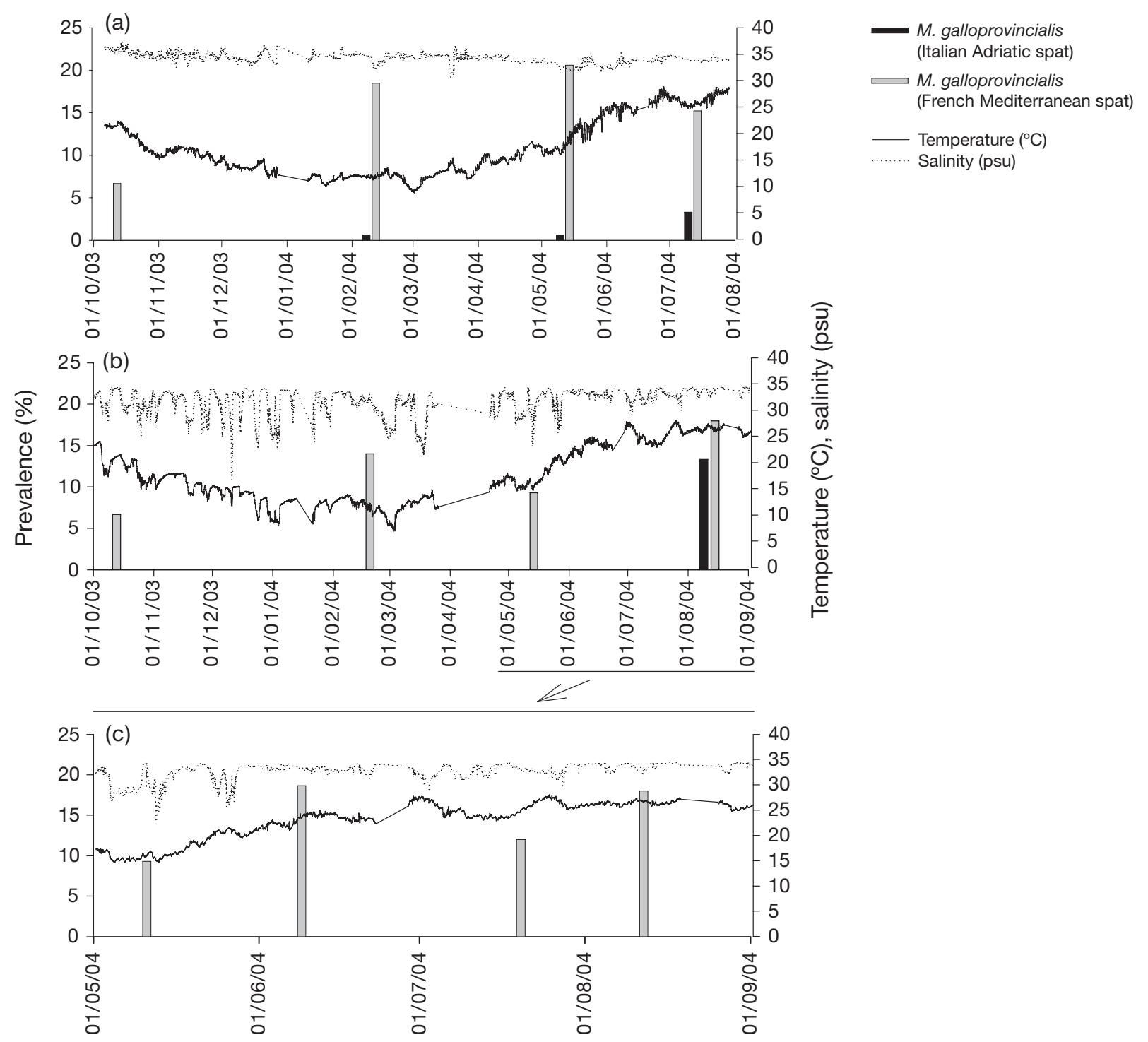

Fig. 3. Marteilia spp. prevalence (\%) in the cultivated bivalves (Mytilus galloprovincialis, Ostrea edulis, Crassostrea gigas) from the Ebre River delta in 2003/2004 period: (a) in Alfacs Bay, (b) in Fangar Bay and (c) in Fangar Bay for French spat mussel during late spring and summer. Complementary environmental data: temperature $\left({ }^{\circ} \mathrm{C}\right)$ and salinity $(\mathrm{psu})$. Dates are d/mo/yr

In June, massive mortalities (100\%) of Ostrea edulis of unknown cause occurred in both bays. Therefore, prevalence data were not available for the entire duration of the experiment. However, data collected in May and June did not show the presence of Marteilia spp. in flat oysters. None of the Crassostrea gigas samples were analysed after the 2003 negative results. Other parasites such as the ciliates Ancistrocoma spp., the trematodes Protoeces spp. and rickettsias were also detected in mussels. For Mytilus galloprovincialis of French origin, parasite prevalence was $2.67 \%$, for both trematodes and ciliates, in the October sample, before the mussels were immersed in the bays. Throughout the year, the 3 types of parasites (ciliates, trematodes and rickettsias were sporadically detected, with prevalence ranging between 0.60 and $2.67 \%$. In addition, cases of proliferative disease recorded as neoplasia were noted in $3.34 \%$ of the individuals of the Alfacs May sample. For the mussels of Italian origin, no parasites were noted in October pre-immersion samples. However, ciliates Ancistrocoma spp. and trematodes Protoeces spp. were detected, with a prevalence of $2 \%$ for both parasites in the Fangar February sample, and rickettsias were detected, with a $0.60 \%$ of prevalence in the Alfacs May sample. Neoplasia was also detected in 1 (out of 150 individuals) mussel in the Fangar June sample. For flat oysters, parasites such as ciliates Ancistro- 


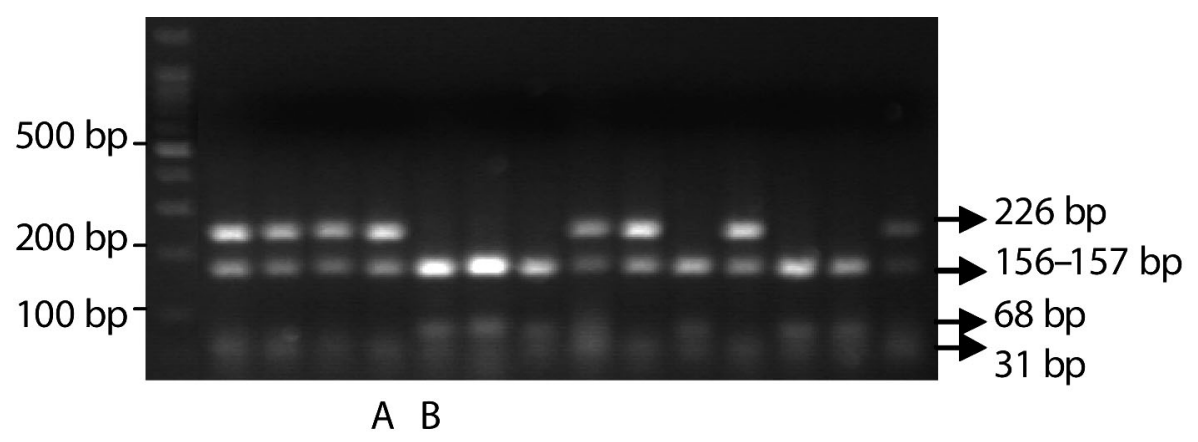

Fig. 4. Marteilia spp. Co-infected flat oyster Ostrea edulis. Electrophoresis gel of HhaI PCR-RFLP on partial ITS Marteilia spp. Lane A corresponds to the Type 'O' profile (3 restriction fragments: 226, 156 and 31 base pairs) and Lane B corresponds to the Type 'M' profile (4 restriction fragments: 156, 157, 68 and 31 base pairs)

coma spp., copepods Myticola spp. and rickettsias were also detected in the Fangar June samples, with higher prevalence rates $(9.33,5.33$ and $6.66 \%$, respectively). In Alfacs Bay, these parasites were not detected in $O$. edulis during the same period.

\section{Marteilia spp. type study}

All the amplicons (14 to 15 amplicons ind. ${ }^{-1}$ ) analysed by PCR-RFLP from 3 of the Marteilia-infected mussels in 2003, showed a $M$. maurini profile according to the definition of Le Roux et al. (2001). However, from the 6 flat oysters analysed by PCR-RFLP, 1 oyster from Alfacs Bay led to the detection of both types, with 8 amplicons of $M$. maurini profile and 6 amplicons of M. refringens profile (Fig. 4).

\section{Zooplankton study}

In the summer of 2004, both copepod abundance and species diversity in the bays were low. However, in October 2003 samples, the number of species and

Table 5. Qualitative abundance of different copepod taxa in the bays of the Ebre River delta in autumn (Au) 2003 and summer (Su) 2004. +++: very abundant; ++: common; +: rare

\begin{tabular}{|lcc|}
\hline Taxon & Abundance & Season \\
\hline Calanoida & & \\
Acartia latisetosa & +++ & $\mathrm{Au}, \mathrm{Su}$ \\
Acartia grani & + & $\mathrm{Au}, \mathrm{Su}$ \\
Acartia clausi & + & $\mathrm{Au}$ \\
Cyclopoida & & $\mathrm{Au}$ \\
Oithona sp. & +++ & $\mathrm{Au}$ \\
Harpaticoida & & \\
Indeterminate species & ++ & \\
\hline
\end{tabular}

number of individuals were higher, with major groups of copepods (Calanoida, Cyclopoida and Harpacticoida) being represented. The study of calanoid copepods revealed the presence of 2 main Acartia species in these samples; the most abundant one was A. latisetosa, and, in lower abundance, A. grani (Paracartia grani) was also present. Some representatives of $A$. clausi were also observed (Table 5). In relation to other copepod groups, Cyclopoida were mainly represented by the genus Oithona, and this taxon was also very abundant. Harpatocoids were less abundant. Regarding the summer 2004 samples, only a few samples, from Alfacs Bay, contained copepod individuals. In these samples, A. latisetosa was the most abundant copepod, with some A. grani being detected. A number of unidentified copepodite stages, crustacean larvae, bivalve larvae and gastropod larvae were also well represented in some of the samples during the same periods.

\section{DISCUSSION}

The Ebre delta is the first Spanish shellfish production site on the Mediterranean coast. The production of bivalves is estimated at 2657 metric tons per year (2004, www.gencat.net/darp). Major cultivated species are the mussels Mytilus galloprovincialis (1700 $\mathrm{t} \mathrm{yr}^{-1}$ ), Pacific oysters Crassostrea gigas (854 t yr ${ }^{-1}$ ) and Japan-

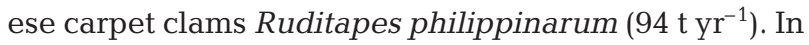
the past, European flat oyster Ostrea edulis culture was also carried out in the bays of the Ebre River delta, but several mortality outbreaks in the 1990s led farmers to replace this species with $C$. gigas. Oyster and mussel culture is traditionally achieved on ropes tied to wooden frames, also called 'bateas'.

From the preliminary data we obtained during our study, the bays of the Ebre Rive delta appear to be provide an interesting natural environmental model to 
study the dynamics of Marteilia species. The cycle of the parasite was completed in the bays, as demonstrated by the infection of uninfected mussels and flat oysters. From this point of view, our results are similar to those previously published by Audemard et al. (2004), with parasite transmission occurring between June and August, when water temperatures are $>17^{\circ} \mathrm{C}$.

Marteilia species were detected in both Mytilus galloprovincialis and Ostrea edulis from Alfacs and Fangar Bays. However, they were not reported in Crassostrea gigas. The presence of $M$. refringens in Pacific oyster C. gigas has previously been reported, but is currently considered as a peculiar and unusual location of the parasite in filter-feeding organisms (Berthe et al. 2004).

Marteilia was detected in mussels all year round. However, the infection of uninfected mussels shows a clear seasonal window, for 2004, between May and July/August, when temperatures are $>17^{\circ} \mathrm{C}$, as occurs in flat oysters (Balouet 1977, Audemard et al. 2001). New infections probably began to occur in late May and June, just after temperatures rose to $>17^{\circ} \mathrm{C}$ (Grizel 1985). However, the high prevalence rates recorded in February, when temperatures are minimal, is not well understood. This phenomenon has also been observed by other investigators (Villalba et al. 1993). Significant and sudden changes in temperatures (like thermal shocks) may trigger some erratic or sporadic event of parasite activation in winter. This is probably true when considering the temperature variations recorded in our model (see Fig. 3).

This may lead to new considerations on parasite transmission, such as a possible mechanism of parasite multiplication, with limited dispersion (no new ropes becoming infected) being activated by changes in cold temperature regimes. Or it may be that transmission exists throughout the year, because mature sporangia occur in all seasons, but different types of intermediate hosts are involved. Another possibility would also be that direct, short-distance transmission occurs (for example, through faeces that may be shed in the close vicinity of individuals belonging to the same rope) in winter time and indirect, long-distance transmission in summer time. By monitoring the dynamics of infection on a monthly basis throughout the year and more frequently during the critical periods, new information on the dynamics of Marteilia can be gained.

Results of our Marteilia type study indicate that, generally, M. maurini would be found in mussels, while $M$. refringens would be found in oysters, but lack of strict host affinity is evident in our data and has also been shown in previous studies (Le Roux et al. 2001, LopezFlores et al. 2004, Novoa et al. 2005). It may be hypoth- esised that in specific situations of high parasitic loads in the environment, a predominant type could infect both flat oysters and mussels. That is what could have happened in the co-infected oysters in the present study. Alfacs Bay supports a higher mussel than flat oyster density, and the possibility of cross-infection occurring (from mussels to flat oysters) is probably high. It is not clear if the types of Marteilia are conspecific or not, and controversial opinions circulate among authors regarding the co-infection. On the other hand, the frequency of detection may vary with the period of the year, and more attention should be given to temporal scaling of the phenomenon.

Strictly speaking, what is usually interpreted as coinfection is rather co-detection, as PCR detection gives no data are available on the actual infection status. Viability and development studies of the Marteilia refringens type in mussels and the $M$. maurini type in flat oysters would be interesting. Unfortunately, the typing techniques currently available do not permit a topographical analysis equivalent to in situ hybridisation or immunohistochemistry. This would be of utmost interest in relation to the risks of transfers of infected animals between geographical regions. Knowledge of the complete cycle of Marteilia spp. would also facilitate experimental cross-infections in the laboratory, to acquire further information for new legislation designed to present transfers of the parasite.

Paracartia grani is considered a potential intermediate host of Marteilia refringens (Audemard et al. 2002), and is present in the both bays. However, this species is not one of the most abundant calanoid copepods in the bays, in contrast with its role in the claire pond model (Audemard et al. 2001). Other species, including Acartia latisetosa, are more abundant during spring, summer and fall, and could constitute better candidates for intermediate hosts in Marteilia cycle. Further investigations of these 2 species and other potential intermediate/alternate hosts will be required to analyse the presence of Marteilia in the zooplankton. Furthermore, experimental comparative infection of $P$. grani by Marteilia spp. from mussels and from oysters could provide interesting information regarding the potential involvement of different copepod species in the cycle of the parasite according to the bivalve host species and Marteilia type.

The Ebre River delta presents perfect qualities to study the dynamics of Marteilia species in a natural environment. The characteristics are similar to those of the claire pond model, at a higher scale of biodiversity and hydrodynamics. This should allow us to study the infection dynamics of the parasite in mussels, as well as in intermediate hosts, in order to further clarify aspects of the life cycle of Marteilia and eventually resolve the remaining enigmas of this parasite. 
Acknowledgements. This study was supported by funds from an INIA pre-doctoral grant provided by the Spanish Minister of Science, the EU Community Reference Laboratory for Mollusc Diseases and the Marie Curie Host Fellowships (No. 405865H/P297815F) provided by the European Commission. We thank CRA for funds from the Molluscs project, coordinated by Dra. Ramon (IRTA). We also thank Dr. Alcaraz (ICM) for help in zooplankton taxonomy, Dr. Estévez for histological advice, Jesús Carles (CADEMAR) for providing bivalve culture material and facilities, and Olga Bellot, Noèlia Gras, $M^{\mathrm{a}}$ Redon, Mireia Juan-Camps, Marta González, Joanna Gil, Susana Sánchez and Guillem Riba for technical work. Thanks to Josep $\mathrm{M}^{\mathrm{a}}$ Reverté and Miquel Rosales for collecting samples.

\section{LITERATURE CITED}

Audemard C, Barnaud A, Collins CM, Le Roux F and others (2001) Claire ponds as an experimental model for Marteilia refringens life-cycle studies: new perspectives. J Exp Mar Biol Ecol 257:87-108

Audemard C, Le Roux F, Barnaud A, Collins C and others (2002) Needle in a haystack: involvement of the Copepoda Paracartia grani in the life-cycle of the oyster pathogen Marteilia refringens. Parasitology 124:315-323

Audemard C, Sajus MC, Barnaud A, Sautour B, Sauriau PG, Berthe FJC (2004) Infection dynamics of Marteilia refringens in flat oyster Ostrea edulis and copepod Paracartia grani in a claire pond of Marennes-Oléron Bay. Dis Aquat Org 61:103-111

Balouet G (1977) Marteilia refringens-considerations of the life cycle and development of Abers disease in Ostrea edulis. In: Haplosporidian and Haplosporidian-like diseases of shellfish, international symposium, Vol 41. Virginia Institute of Marine Science, Gloucester Point, VA, p 64-66

Berthe FCJ, Pernas M, Zerabib M, Haffner P, Thebault A, Figueras AJ (1998) Experimental transmission of Marteilia refringens with special consideration of its life cycle. Dis Aquat Org 34:135-144

Berthe FCJ, Le Roux F, Peyretaillade E, Peyret P, Rodriguez D, Gouy M, Vivares CP (2000) Phylogenetic analysis of the small subunit ribosomal RNA of Marteilia refringens validates the existence of phylum Paramyxea (Desportes and Perkins, 1990). J Eukaryot Microbiol 47:288-293

Berthe F, Le Roux F, Adlard RD, Figueras A (2004) Marteiliosis in molluscs: a review. Aquat Living Resour 17:433-448

Camp J, Delgado M (1987) Hidrografía de las bahías del delta del Ebro. Investig Pesq 51:351-369

Carrasco N, Furones MD, Durfort M, Santmartí M (2001) Survey for Marteilia refringens and Bonamia ostreae in the wild and cultivated populations of the flat oyster (Ostrea edulis) in the River Ebro delta (Catalonian, Spain). In: Proc 10th Int Conf European Assoc Fish Pathol. European Association of Fish Pathologists, Dublin, p 211

Comps M (1970) Observations sur les causes d'une mortalité anormal des huîtres plates dans le bassin de Marennes. Rev Trav Inst Pech Marit 34:317-326

Comps M (1979) Étude du cycle de Marteilia refringens dans l'Étang de Thau. Rapp P-V Reun Cons Int Explor Mer $\mathrm{F}: 1-5$

Comps M, Joly JP (1980) Experimental contamination of
Mytilus galloprovinicialis Lmk by Marteilia refringens. Sci Pêche 301:19-21

Delgado M (1987) Fitoplancton de las bahías del delta del Ebro. Invest Pesq 51:517-548

Delgado M, Camp J (1987) Abundancia y distribución de nutrientes inorgánicos disueltos en las bahías del delta del Ebro. Invest Pesq 51:427-441

Durfort M, Bigas M, Bozzo MG, Ferrer J and others (1996) Biodiversidad parasitaria en moluscos bivalvos de la costa Mediterránea. In: XII Bienal de la Real Sociedad Española de Historia Natural, Madrid. Available at: http://rshn.geo.ucm.es/bienal/12/b12-znar.htm

Grizel H (1985) Etude des récentes épizooties de l'huitre plate (Ostrea edulis Linné) et leur impact sur l'ostréiculture bretonne. Thesis doctoral, Departement de Sciences, Université des Sciences et Techniques du Languedoc, Montpellier

Grizel H, Comps M, Bonami JR, Cousserans F, Duthoit JL, Pennec M (1974) Epizooty of the common oyster Ostrea edulis, Part 1. Study of the agent of digestive gland disease in Ostrea edulis Linne. Sci Pêche 240-241:1-30

Herrbach B (1971) Sur une affection parasitarie de la glande digestive de l'huître plate, Ostrea edulis Linne. Rev Trav Inst Pech Marit 35:79-87

Le Roux F, Audemard C, Barnaud A, Berthe F (1999) DNA probes as potential tools for the detection of Marteilia refringens. Mar Biotechnol 1:588-597

Le Roux F, Lorenzo G, Peyret P, Audemard C and others (2001) Molecular evidence for the existence of two species of Marteilia in Europe. J Euk Microbiol 48:449-454

Longshaw M, Feist SW, Matthews RA, Figueras A (2001) Ultrastructural characterisation of Marteilia species (Paramyxea) from Ostrea edulis, Mytilus edulis and Mytilus galloprovincialis. Dis Aquat Org 44:137-142

Lopez-Flores I, de la Herran R, Garrido-Ramos MA, Navas JI, Ruiz-Rejon C, Ruiz-Rejon M (2004) The molecular diagnosis of Marteilia refringens and differentiation between Marteilia strains infecting oysters and mussels based on the rDNA IGS sequence. Parasitology 129:411-419

Novoa B, Posada D, Figueras A (2005) Polymorphisms in the sequences of Marteilia internal transcribed spacer region of the ribosomal RNA genes (ITS-1) in Spain: genetic types are not related with bivalve hosts. J Fish Dis 28: 331-338

Ossiander FJ, Wedemeyer G (1973) Computer program for sample sizes required to determine disease incidence in fish population. J Fish Res Board Can 30:1383-1384

Perkins FO (1976) Ultrastructure of sporulation in the European flat oyster pathogen, Marteilia refringens-taxonomic implications. J Protozool 23:64-74

Riera V, Santmarti M, Durfort M (1993) Presence of Marteilia refringens, in the cultures of bivalve molluscs in the Catalan littoral. In: Actas del IV Congreso Nacional de Acuicultura, Centro de Investigaciones Mariñas, Pontevedra, p 539-544

Sambrook J, Fritsch EF, Maniatis T (1989) Molecular cloning: a laboratory manual. Cold Spring Harbor Laboratory Press, New York

Villalba A, Mourelle SG, López MC, Carballal MJ, Azevedo C (1993) Marteiliasis affecting cultured mussels Mytilus galloprovincialis of Galicia (NW Spain). I. Etiology, phases of the infection, and temporal and spatial variability in prevalence. Dis Aquat Org 16:61-72 